\title{
PENGARUH MODEL PEMBELAJARAN VAK (VISUAL, AUDITORY,KINESTETIK)TERHADAP KEMAMPUAN MENULIS KARYA ILMIAH OLEH MAHASISWA STAIS TEBINGTINGGI
}

\author{
Mursid (mursid.tp@gmail.com) \\ Erikson Simbolon (simboloneriks@gmail.com) \\ Jusua Barus (jusuabarus18@gmail.com) \\ Retno Sayekti (retnosayekti69@uinsu.ac.id) \\ Universitas Negeri Medan
}

\begin{abstract}
ABSTRAK
Penelitian ini bertujuan untuk mengetahui adanya pengaruh model pembelajaran VAK (Visual, Auditory, Kinestetik) terhadap kemampuan mahasiswa STAIS Tebingtinggi dalam menulis karya ilmiah. Dari keseluruhan populasi di perguruan tinggi ini ditetapkan 32mahasiswa yang dipilih secara acak. Instrumen penelitian yang digunakan adalah tes kemampuan menulis karya ilmiah.Metode penelitian yang digunakan adalah one group pre-test post-test design. Berdasarkan hasil penelitian kemampuan mahasiswa dalam menulis karya ilmiahsebelum menggunakan model VAK (Visual, Auditory, Kinestetik) yang dapat meningkatan kemampuan menyusun karya ilmiahmenunjukkan hasil dengan nilai tertinggi 86 dan nilai terendah 60 yang diperoleh dari 32 mahasiswa, yang memiliki nilai rata-rata 74,41 dan berada pada kategori cukup. Kemampuan menulis karya ilmiah sesudah menggunakanmodel VAK (Visual, Auditory, Kinestetik) menunjukkan hasil dengan nilai tertinggi 94 dan nilai terendah 68 dari 32 mahasiswa, yang memiliki nilai rata-rata 82,56 dan berada pada kategori baik. Jadi, dapat disimpulkan bahwa ada pengaruh model pembelajaran VAK (Visual, Auditory, Kinestetik) terhadap kemampuan mahasiswa STAIS Tebingtinggi dalam menulis karya ilmiah.
\end{abstract}

Kata Kunci:Model VAK (Visual, Auditory, Kinestetik), Karyallmiah.

\section{PENDAHULUAN}

Kemampuan menulis setiap mahasiswatidak diperoleh secara alamiah, namun diperoleh dari proses latihan dan pembelajaran secarasungguh-sungguh sebagai bekal pendidikan di perguruan tinggi.Menulismerupakan kegiatan yang sifatnyaberkelanjutan sehingga pembelajarannya perludilakukan sejak awal di SD secaraberkesinambungan sebagai bekal belajarmenulis di tingkat selanjutnya (Sitaresmi, 2010:1). Selaras dengan pendapat Cahyani dan Hodijah (2007:10) bahwaketerampilan menulis paling rumit 
karenamenulis bukanlah sekadar menyalin kata dankalimat, melainkan juga mengembangkan danmengungkapkan pikiran-pikiran dalam suatutulisan yang teratur.

Kemampuan menulis karya ilmiah sangat penting untuk mahasiswa. Membuat sebuah karya ilmiah termasuk salah satu kewajiban seorang mahasiswa. Menyusun karya ilmiah biasa digunakan mahasiswa hanya untuk membuat makalah, laporan akhir program kerja lapangan, dan laporan praktikum. Penyusunan karya ilmiah yang digunakan untuk tugas-tugas akademik tersebut akan sangat berguna bagi mahasiswa dalam penyusunan skripsi dan artikel sebagai prasyarat untuk dapat memperoleh gelar sarjana.

Praktek pembuatan karya ilmiah berupa tugas-tugas akademik yang dikerjakan oleh mahasiswa masih banyak ditemukan kesalahan. Faktanya banyak mahasiswa mengalami kesulitan dalam menulis karya ilmiah tersebut. Hal ini terlihat dari kurang sistematisnya karya ilmiah yang telah dibuat, kemudian masih banyak ditemukan kesalahan pada tata bahasa di karya ilmiah tersebut. Kurangnya pemahaman terhadap masalah yang dibahas pada karya ilmiah juga sering menjadi penghambat mahasiswa dalam menyusun karya ilmiah yang baik. Masalah-masalah di atas menjadi dasar penelitian ini dilaksanakan. Penelitian ini bertujuan untuk mengetahui adanya pengaruh yang signifikan terhadap kemampuan mahasiswa dalam menulis karya ilmiah setelah menggunakan model pembelajaran VAK (Visual, Auditori, Kinestetik).

Seperti penelitian yang telah dilakukan oleh Fathonah (2016) terlihat adanya peningkatan motivasi peserta didik dalam kegiatan pembelajaran menulis puisi melalui VAK (Visual, Auditori, Kinestetik). Kemudian, penelitian yang telah dilakukan oleh Setiawan (2015), menunjukkan bahwa hasil belajar peserta didik dalam memahami materi listrik dinamis mengalami peningkatan dari nilai rata-rata 41,9\% ke 91,41\%. Kedua jurnal tersebut membuktikan bahwa hasil belajar peserta didik bisa ditingkatkan melalui penggunaan model VAK (Visual, Auditory, Kinestetik) dan Penulis ingin menggunakan model VAK dalam meningkatkan kemampuan mahasiswa STAIS Tebingtinggi menulis karya ilmiah. 


\section{KAJIAN TEORI}

\section{Model Pembelajaran VAK (Visual, Auditory, Kinestetik)}

Menurut Arsyad (2008: 19) mediapembelajaran dapat memenuhi tiga fungsiutama yaitu memotivasi minat atau tindakan,menyajikan informasi, dan memberi instruksi.Hasil yang diharapkan melahirkan minat danmerangsang peserta didik untuk bertindak.Model pembelajaran VAK (Visual, Auditory, Kinestetik) merupakan model pembelajaran yang mengoptimalkan modalitas belajar yaitu Visual, Auditory, dan Kinestetik untuk membuatmahasiswa merasa nyaman dan memaksimalkan penerimaan materi secara merata dan untuk meningkatkan hasil belajar peserta didik. "Pemanfaatan dan pengembangan potensi siswa dalam proses belajar mengajar dengan memerhatikan kebutuhan dan gaya belajar siswa hal ini, menyangkut dengan bagian visual (menggunakan media dua dimensi seperti grafik, gambar, chart, model dan sebagainya), Auditory lebih mengutamakan pendengaran atau semacam yang diucapkan, dan kinestetik dengan melakukan kegiatan tertentu."Shoimin2016:227.

Pembelajaran VAK (Visual, Auditori, Kinesthetic) memiliki prinsip yang sejalan dengan Accelerated Learning, teori otak kanan/kiri; teori otak triune; pilihan modalitas (visual, auditorial dan kinestetik); teori kecerdasan ganda; pendidikan (holistic) menyeluruh; belajar berdasarkan pengalaman; belajar dengan simbol. Pembelajaran VAK (Visual, Auditori, Kinesthetic) berdasar pada ilmu kognitif modern yang menyebutkan tipe belajar paling baik adalah melibatkan emosi, seluruh tubuh, semua indera, dan segenap kedalaman sertakeluasan pribadi, menghormati gaya belajar individu lain dengan menyadari bahwa orang belajar dengan cara-cara yang berbeda (unik).

Dikarenakan pembelajaran VAK (Visual, Auditori, Kinesthetic) sejalan dengan gerakan Accelerated Learning (AL), maka prinsipnya juga sejalan dengan AL yaitu:

1) pembelajaran melibatkan seluruh pikiran dan tubuh

2) pembelajaran berarti berkreasi bukan mengkonsumsi.

3) kerjasama membantu proses pembelajaran

4) pembelajaran berlangsung pada benyak tingkatan secara simultan

5) belajar berasal dari mengerjakan pekerjaan itu sendiri dengan umpan balik.

6) emosi positif sangat membantu pembelajaran. 
7) otak-citra menyerap informasi secara langsung dan otomatis.

Pembelajaran VAK (Visual, Auditori, Kinesthetic) dapat direncanakan dandikelompokan dalam empat tahap:

1. Tahap Persiapan (kegiatan pendahuluan)

Pada tahap ini guru membangkitkan minat siswa, memberikan perasaanpositif mengenai pengalaman belajar yang akan datang, dan menempatkan merekadalam situasi optimal untuk belajar.

2. Tahap Penyampaian (kegiatan inti)

Pada tahap ini guru hendaknya membantu siswa menemukan materi belajar yang baru dengan cara menari, menyenangkan, relevan, melibatkan pancaindera,dan cocok untuk semua gaya belajar.

3. Tahap Pelatihan (kegiatan inti)

Pada tahap ini guru hendaknya membantu siswa mengintegrasikan dan menyerap pengetahuan dan keterampilan baru dengan berbagai cara.

\section{Tahap Penampilan Hasil (kegiatan penutup)}

Pada tahap ini guru hendaknya membantu siswa menerapkan dan memperluas pengetahuan atau keterampilan baru mereka pada pekerjaan sehinggahasil belajar akan melekat dan penampilan hasil akan terus meningkat.

\section{Karya Tulis Ilmiah}

Karya ilmiah adalah suatu tulisan yang membahas suatu masalah tertentudengan menggunakan kaidah-kaidah keilmuan. Kaidah-kaidah keilmuan itumencakup penggunaan metode ilmiah dan pemenuhan prinsip-prinsipkeilmiahan, seperti: objektif, logis, empiris, sistematis, lugas, jelas, dankonsisten. Karya ilmiah dapat dipilah menjadi dua, (i) karya ilmiah yangditulis dengan berdasar pada hasil penelitian, dan (ii) karya ilmiah yang ditulisdengan berdasar pada hasil pemikiran serius. Baik jenis (i) maupun (ii), dalampenulisannya tetap menggunakan metode analisis masalah yang bersifatmendekati kebenaran (ilmiah). 
Lyons dan Heasley (2009) mengatakanbahwa ada banyak jenis karya tulisilmiah dalam bahasa Inggris.Perbedaan dari sejumlah tulisanakademik tersebut terletak padaperbedaan disiplin ilmu serta cara karya tulis ilmiahdibuat dan cara mempublikasikannya.Penulisan karya ilmiah harus pula dilakukan berdasarkan kerangka berpikir ilmiah yang meliputi ruang lingkup tulisan, pembatasan masalah, metodologi dan sistematika penulisan, serta penggunaan bahasa yang baik dan benar. Karena kegiatan ilmiah banyak jenisnya.Jadi, jenis karya tulis ilmiah juga banyak macamnya. Karya tulis ilmiah memiliki banyak jenis, seperti: artikel, kertas kerja, laporan penelitian, makalah, skripsi, tesis, disertasi. Karya tulis ilmiah berbeda bentuk penyajiannya sehubungan dengan berbedanya tujuan penulisan serta media yang mempublikasinya.

Ciri-ciri karya ilmiah yang baik antara lain:

1. Mendalam/Tuntas, artinya, topik pembahasan yang diangkat dalam karya ilmiah dikupas secara mendalam, mendetail sampai ke akar-akarnya. Agar sebuah topk dapat dibahas dengan tuntas, maka seorang penulis hendaknya tidak mengangkat topik yang terlalu luas. Contoh "Pemberantasan Korupsi di Indonesia"

2. Objektif, segala keterangan yang dikemukakan dalam tulisan itu adalah benar dan apa adanya sesuai dengan data dan fakta yang diperoleh. Keobjektifan karya ilmiah dapat dicapai dengan tersedianya data literatur dan data lapangan yang memadai (datanya harus representatif), dan jangan sekali-kali seorang penulis memanipulasi data.

3. Sistematis, artinya, uraian disusun menurut pola tertentu sehingga jelas urutan dan kaitan antara unsur-unsur tulisan (berkesinambungan, berurutan, berkaitan).

4. Cermat, seorang penulis harus berupaya menghindari kesalahan/kekeliruan baik dalam pengutipan, penyajian data, dan penulisan huruf.

5. Lugas, artinya pembicaraan langsung pada persoalan yang dikaji tanpa basa-basi.

6. Tidak emosional, artinya tanpa melibatkan perasaan.

7. Logis, maksudnya segala keterangan yang disajikan memiliki dasar dan alasan yang masuk akal.

8. Bernas, artinya meskipun uraian itu singkat, isinya padat. 
9. Jelas, keterangan yang dikemukakan dapat mengungkap makna secara jernih sehingga mudah dipahami pembaca.

10. Terbuka, tidak menutup kemungkinan adanya pendapat baru yang tidak sesuai dengan apa yang ditulis dalam karya ilmiah tersebut.

11. Menggunakan bahasa baku, tepat, ringkas, dan jelas

\section{METODOLOGI PENELITIAN}

Penelitian ini dilaksanakan di STAIS Tebingtinggi. Pendekatan pada penelitian ini adalah pendekatan kuantitatif. Sugiyono (2016: 2) menyebutkan bahwa metode penelitian adalah cara ilmiah untuk mendapatkan data dengan tujuan dan kegunaan tertentu. Metode yang digunakan dalam penelitian ini adalah metodepenelitianone group pretest posttest design.

Arikunto (2014: 124) menyatakan bahwa pre-test post-test group design yaitu eksperimen yang dilaksanakan pada satu kelompok saja tanpa pembanding. Desain dengan teknik ini memberikan perlakuan yang sama pada setiap subjek sampel tanpa memperhitungkan dasar kemampuan yang dimiliki. Instrumen dalam penelitian ini adalah berupa tes penugasan untuk kerja dalam bentuk tes kemampuan menulis karya ilmiah. Tes ini dilakukan dengan pre-test post-test untuk mendapatkan data kemampuan menulis teks laporan hasil observasi setelah diadakan perlakuan dengan membandingkan hasil yang telah diperoleh. Kesimpulannya siswa yang menjadi sampel dalam penelitian ini akan mendapatkan hak yang sama yaitu tes awal, perlakuan menggunakan media VAK dalam pembelajaran adalah tes akhir. Dalam penelitian ini data yang digunakan adalah data kuantitatifkarena gambaran datanya menggunakan ukuran, jumlah, atau frekuensi yaitu nilai kemampuan mahasiswa dalam menulis karya ilmiah.

\section{HASIL PENELITIAN DAN PEMBAHASAN}


Pada tahap awal penelitian akan dilaksanakan pengumpulan data kemampuan menulis karya ilmiah oleh mahasiswa STAIS Tebingtinggi. Setelah pelaksanaan pre-test tersebut didapatlah data sebagai berikut:

Tabel 1 Identifikasi Kecenderungan di Kelas Pre-test

\begin{tabular}{c|c|c|c}
\hline Frekuensi & Frekuensi Absolut & Frekuensi Relatif & Kategori \\
\hline $85-100$ & 4 & $12,5 \%$ & Sangat baik \\
\hline $75-84$ & 12 & $37,5 \%$ & Baik \\
\hline $65-74$ & 13 & $40,6 \%$ & Cukup \\
\hline $55-64$ & 3 & $9,4 \%$ & Kurang \\
\hline $00-54$ & 0 & $0 \%$ & Sangat kurang \\
\hline & $\mathbf{3 2}$ & $\mathbf{1 0 0 \%}$ & \\
\hline
\end{tabular}

Berdasarkan data di atas, dapat diketahui bahwa kemampuan menulis karya ilmiah sebelum menggunakan model VAK termasuk dalam lima kategori, yaitu kategori sangat baik sebanyak 4 orang atau 12,5\%, kategori baik sebanyak 12 orang atau 37,5\%, kategori cukup sebanyak 13 orang atau 40,6\%, kategori kurang sebanyak 3 orang atau 9,4\%, dan kategori sangat kurang tidak ada atau 0\%. Identifikasi kecenderungan di kelas pre-test termasuk kategori cukup.Hasil rata-rata kemampuan menulis karya ilmiah sebelum menggunakan model VAK 74,41 dari jumlah siswa sebanyak 32 orang dengan nilai tertinggi 86 dan nilai terendah 60.

Tahap selanjutnya pada penelitian ini diberlakukan model VAK pada saat pembelajaran menulis karya ilmiah. Pendidik menampilkan sebuah video pembelajaran mengenai karya tulis ilmiah yang memuat ciri, jenis, dan sistematika penulisan sebuah karya tulis ilmiah. Peserta didik mengamati dan menuliskan point-point penting dari video tersebut. Kemudian, siswa mulai bertanya mengenai suatu hal yang belum dipahami. Setelahnya, pendidik kembali memberikan pertanyaan kepada peserta didik dan mengamati bagaimana siswa menanggapi masalah yang dihadapi. Pendidik memberikan satu contoh mengenai karya tulis ilmiah berdasarkan buku panduan menulis karya ilmiah. Setelah peserta didik cukup memahami tentang ciri, jenis, dan sistematika penulisan sebuah karya tulis ilmiah, kemudian dilanjutkan dengan menampilkan sebuah video mengenai yang akan menjadi tema dalam menulis sebuah karya ilmiah.Setelah pemberlakuan model VAK, pelaksanaan post-test dilakukan untuk mengukur apakah ada perubahan setelah diterapkan model VAK. Berikut adalah data hasi post-test: 
Table 2 Identifikasi Kecenderungan di Kelas Post-test

\begin{tabular}{c|c|c|c}
\hline Frekuensi & Frekuensi Absolut & Frekuensi Relatif & Kategori \\
\hline $85-100$ & 16 & $50 \%$ & Sangat baik \\
\hline $75-84$ & 7 & $21,9 \%$ & Baik \\
\hline $65-74$ & 9 & $28,1 \%$ & Cukup \\
\hline $55-64$ & 0 & $0 \%$ & Kurang \\
\hline $00-54$ & 0 & $0 \%$ & Sangat kurang \\
\hline & $\mathbf{3 2}$ & $\mathbf{1 0 0 \%}$ & \\
\hline
\end{tabular}

Berdasarkan data di atas, dapat diketahui bahwa kemampuan menulis karya ilmiah menggunakan model VAK termasuk dalam lima kategori, yaitu kategori sangat baik sebanyak 16 orang atau 50\%, kategori baik sebanyak 7 orang atau 21,9\%, kategori cukup sebanyak 9 orang atau 28,1\%, kategori kurang tidak ada atau $0 \%$, dan kategori sangat kurang tidak ada atau $0 \%$. Identifikasi kecenderungan di kelas post- test termasuk kategori sangat baik. Hasil rata-rata kemampuan menulis karya ilmiah sesudah menggunakan model VAK 82,56 dari jumlah mahasiswa sebanyak 32 orang dengan nilai tertinggi 94 dan nilai terendah 68.

Dengan demikian, kemampuan menulis karya ilmiah oleh mahasiswa STAIS Tebingtinggi telah mengalami peningkatan baik secara proses maupun setelah diberi tindakan menggunakan model VAK. Hal ini membuktikan bahwamodel VAK(Visual, Auditori, Kinesthetic) adalah model pembelajaran yang signifikan berdasarkan pengalaman yang dapat digunakan pendidik dalam menyampaikan materi ajarnya kepada peserta didik. Dengan model VAK(Visual, Auditori, Kinesthetic)dalam pembelajaran, pendidik dapat meningkatkan hasil kemmapuan mahasiswa dalam menulis karya ilmiah. Hal tersebut terbukti dari hasil penelitian dan data yang telah diperoleh.

\section{Perbedaan Standar Eror Kelompok Pre Test dan Post Test}

$$
\begin{gathered}
S E M_{1}-M_{2}=\sqrt{(S E M 1)^{2}+(S E M 2)^{2}} \\
S E M_{1}-M_{2}=\sqrt{1,35^{2}+1,51^{2}} \\
S E M_{1}-M_{2}=2,02
\end{gathered}
$$

\section{Pengujian Hipotesis}


Sebelum diuji persyaratan data, hipotesis tersebut diubah menjadi hipotesis nihil (Ho) yaitu tidak terdapat pengaruh yang signifikan antara pengguaan model VAK(Visual, Auditory, Kinestetik) terhadap kemampuan menulis karya ilmiah oleh mahasiswa STAIS Tebingtinggi. 


\section{Uji Normalitas Data}

Uji normalitas yang digunakan adalah uji normalitas Liliefors. Berikut tabel uji normalitas kelompok pre-test.

Tabel 3 Uji Normalitas Data Kelompok Pre-Test

\begin{tabular}{c|c|c|c|c|c|c}
\hline $\mathrm{X}$ & $\mathrm{F}$ & Fkum & $\mathrm{Z}$ & $\mathrm{F}(\mathrm{Zi})$ & $\mathrm{S}(\mathrm{Zi})$ & $\mathrm{L}$ \\
\hline 60 & 3 & 3 & $-1,92$ & 0,0274 & 0,094 & 0,0666 \\
\hline 67 & 5 & 8 & $-0,99$ & 0,1611 & 0,25 & 0,0889 \\
\hline 73 & 8 & 16 & $-0,19$ & 0,4247 & 0,5 & 0,0753 \\
\hline 77 & 8 & 24 & 0,35 & 0,6368 & 0,75 & 0,1132 \\
\hline 83 & 4 & 28 & 1,15 & 0,8749 & 0,875 & 0,0001 \\
\hline 86 & 4 & 32 & 1,55 & 0,9394 & 1 & 0,0606 \\
\hline
\end{tabular}

\section{L hitung 0,1132}

Uji normalitas yang digunakan adalah uji normalitas Liliefors. Berikut tabel uji normalitas kelompok post test.

Tabel 4 Uji Normalitas Data Kelompok Post-Test

\begin{tabular}{c|c|c|c|c|c|c}
\hline $\mathrm{X}$ & $\mathrm{F}$ & Fkum & $\mathrm{Z}$ & $\mathrm{F}(\mathrm{Zi})$ & $\mathrm{S}(\mathrm{Zi})$ & $\mathrm{L}$ \\
\hline 68 & 4 & 4 & $-1,73$ & 0,0418 & 0,125 & 0,0832 \\
\hline 74 & 5 & 9 & $-1,02$ & 0,1539 & 0,281 & 0,1271 \\
\hline 80 & 7 & 16 & $-0,30$ & 0,3821 & 0,5 & 0,1179 \\
\hline 86 & 4 & 20 & 0,41 & 0,6591 & 0,625 & 0,0341 \\
\hline 90 & 8 & 28 & 0,88 & 0,8106 & 0,875 & 0,0644 \\
\hline 94 & 4 & 32 & 1,36 & 0,9131 & 1 & 0,0869 \\
\hline
\end{tabular}

\section{L hitung 0,1271}

Berdasarkan harga perhitungan di atas maka harga yang paling besar diantara hargaharga mutlak selisih tersebut $\left(\mathrm{L}_{\text {hitung }}\right)=0,1271$. Kemudian nilai hitung dikonsultasikan dengan nilai kritis $\mathrm{L}$ dengan taraf $\mathrm{a}=0,05$ (95\%), diketahui $(\mathrm{N}=32)$ Ltabel $=0,1566$. Dengan demikian Lhitung < Ltabel yaitu $(0,1271<0,1566)$, hal ini membuktikan bahwa data dari kelas post test berdistribusi normal.

Tabel 5 Pengujian Normalitas Data Penelitian

\begin{tabular}{l|l|l|l|l}
\hline No & Kelompok & Lhitung & Ltabel & Status \\
\hline 1. & Pre test & 0,1132 & 0,1566 & Normal \\
\hline 2. & Post test & 0,1271 & 0,1566 & Normal \\
\hline
\end{tabular}




\section{Uji Homogenitas}

Uji homogenitas varians untuk menguji kesamanan variabel. Untuk menguji pretest dan post test digunakan untuk rumus:

$$
\begin{array}{r}
F=\frac{S 2}{S 1}=F=\frac{S y}{S x} \\
F=\frac{8,564}{7,612}
\end{array}
$$

$F=1,12$

Tabel 6 Pengujian Homogenitas Data Penelitian

\begin{tabular}{l|l|l|c|c}
\hline No & Kelompok & Fhitung & Ftabel & Status \\
\hline 1. & Pre test & \multirow{2}{*}{1,12} & 4,17 & $\begin{array}{c}\text { Homogen } \\
\text { Karena Fhitung } \\
\text { < Ftabel }\end{array}$ \\
\hline 2. & Post test & & & \\
\hline
\end{tabular}

\section{Perhitungan Uji Hipotesis}

Berdasarkan pengujian normalitas dan homogenitas dari kelompok pre test dan kelompok post test, hasilnya menunjukkan bahwa persyaratan analisis dalam penelitian ini berdistribusi normal dan bervariasi sampel homogen. Sehingga dapat dilanjutkan pada pengujian lebih lanjut yaitu pengujian hipotesis dengan uji “t” perhitungannya sebagai berikut:

$$
\begin{gathered}
t=\frac{M_{1-M_{2}}}{S E M_{1-M_{2}}} \\
t=\frac{82,56-74,41}{2,02} \\
t=\frac{8,15}{2,02} \\
t=4,03
\end{gathered}
$$

\section{KESIMPULAN}

Berdasarkan hasil penelitian, kemampuan menulis karya ilmiah oleh STAIS Tebingtinggi sebelum menggunakan modelpembelajaran VAK (Visual, Auditory, 
Kinestetik) menunjukkan hasil dengan nilai tertinggi 86 dan nilai terendah 60 yang diperoleh dari 32 sampel, yang memiliki nilai rata-rata 74,41 dan berada pada kategori cukup. Data kelompok pre-test berstatus normal dan homogen.kemampuan menulis karya ilmiah oleh STAIS Tebingtinggi setelah menggunakan modelpembelajaran VAK (Visual, Auditory, Kinestetik)menunjukkan hasil dengan nilai tertinggi 94 dan nilai terendah 68 dari 32 sampel yang memiliki nilai rata-rata 82, 56 dan berada pada kategori baik. Data kelompok post-test berstatus normal dan homogen. Maka,dapat diambil kesimpulan bahwa modelpembelajaran VAK (Visual, Auditory, Kinestetik) berpengaruh terhadap kemampuan menulis karya ilmiah oleh mahasiswa STAIS Tebingtinggi.

\section{DAFTAR PUSTAKA}

Arikunto, Surhasimi. 2014. Prosedur Penelitian suatu Pendekatan Praktik. Jakarta: PT. Rineka Cipta.

Arsyad, A. 2008. Media pembelajaran. Jakarta:Rajagrafindo Persada.

Cahyani, I dan Hojidah. (2007). Kemampuan Berbahasa di Sekolah Dasar. Bandung. UPI Press.

Fathonah, Siti. 2016. Peningkatan Keterampilan Menulis Puisi Melaui Model VAK pada Siswa Kelas VII B SMP NEGERI 2 Adimulyo Tahun Pembelajaran 2016/2017. Semnasbahtera. Hal. 107-115

Lyons, L.H and Heasley.B Study Writing( United Kingdom: Canbridge,2009).

Setiawan. 2015. Optimalisasi Hasil Belajar Siswa Melalui Penerapan Model Pembelajaran Kooperatif Tipe VAK (Visual, Auditory, Kinestetik). Berkata Ilmiah Pendidikan Fisika. Vol 3(2), hal 87-92

Sitaresmi, N. (2010). Model Pembelajaran Deskripsi. [Online]. Tersedia:http://file.upi.edu/ai.php?dir=Direktori/C\%20-\%20FPBS/JUR.\%20 PEND.\%20BHS.\%20DAN\%20SASTRA\%20INDONESIA/.

Shoimin, Aris. 2016. 68 Model Pembelajaran Inovatif dalam Kurikulum 2013. Yogyakarta: Ar-Ruzz Media

Sugiyono. 2017. Metode Penelitian Pendidikan: Pendekatan Kuantitatif, Kualitatif, dan $R \& D$. Bandung: Alfabeta 
